Utah State University

DigitalCommons@USU

All U.S. Government Documents (Utah Regional U.S. Government Documents (Utah Regional Depository)

1981

\title{
Off-Road Vehicular Destabilization of Hillslopes: The Major Contributing Factor to Destructive Debris Flows in Ogden, Utah, 1979
}

John K. Nakata

Follow this and additional works at: https://digitalcommons.usu.edu/govdocs

Part of the Geology Commons

\section{Recommended Citation}

Nakata, John K., "Off-Road Vehicular Destabilization of Hillslopes: The Major Contributing Factor to Destructive Debris Flows in Ogden, Utah, 1979" (1981). All U.S. Government Documents (Utah Regional Depository). Paper 570.

https://digitalcommons.usu.edu/govdocs/570

This Report is brought to you for free and open access by the U.S. Government Documents (Utah Regional Depository) at DigitalCommons@USU. It has been accepted for inclusion in All U.S. Government Documents (Utah Regional Depository) by an authorized administrator of DigitalCommons@USU. For more information, please contact digitalcommons@usu.edu.

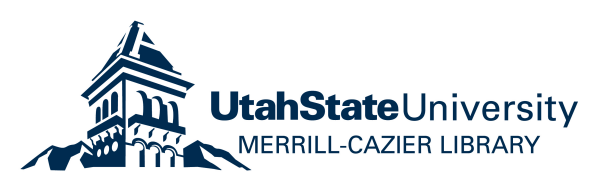


OFP-ROAD VEHICULAR DESTABILIZATION OF HILLSLOPES THE MAJOR CONTRIBUTING FACTOR TO DESTRUCTIVE DEBRTS FLOWS IN OGDEN, UTAH, 1979

by

John K. Nakata

Open-File Report

$81-258$

This report is preliminary and

has not been edited or reviewed

for coiformity with Geolngical

Survey standards or nomenclature
INTRODUCTION:

A severe rain storm on August 17 and 18, 1979, caused major flood damage in urban areas of east 0gden, Utah. At least $3.85 \mathrm{~cm}$ of rain fell in a 7 hour-period. The severity of damage was dramatically increased by water

diverted frow the Brigham-Ogden Canal, when it was clogged by a debris flow in the vicinity of Third, Jaylor, and Polk Streets (Fig. 1).

The purpose of this investigation is to ascertain the sequence of events that followed the storm, and to quantify the processes insofar as possible.

An inspection of the area on September 21-25, 1979, and the subsequent study, indicated that the principal cause of damage was a combination of two factors: (1) channelization of runoff and ercsion of off-road vehicle (ORV) trails clogged the Brigham-Ogden Canal, and (2) the diverted canal water eroded a notch in the alluvial fan and terrace deposits below, which then combined with the debris eroding from the ORV trails to bury cownslope structures.

PHYSICAL SETTING :

Surficial materials along the mountain front in east Ogden are derived primarily from the Precambrien Farmington Canyon Complex, which consists of medium- to coarse-grained gneissic quartz monzonite (Sorensen and Crittenden, 1972). 01der alluvial fan- and terrace- deposits from Pleistocene Lake Bonneville at the base of the range front are locally covered by unconsolidated material consisting of boulders, cobbles, gravel, sand, and silt. These areas are partly stabilized by grasses, small shrubs, smooth sumac, and Gambel oak. 


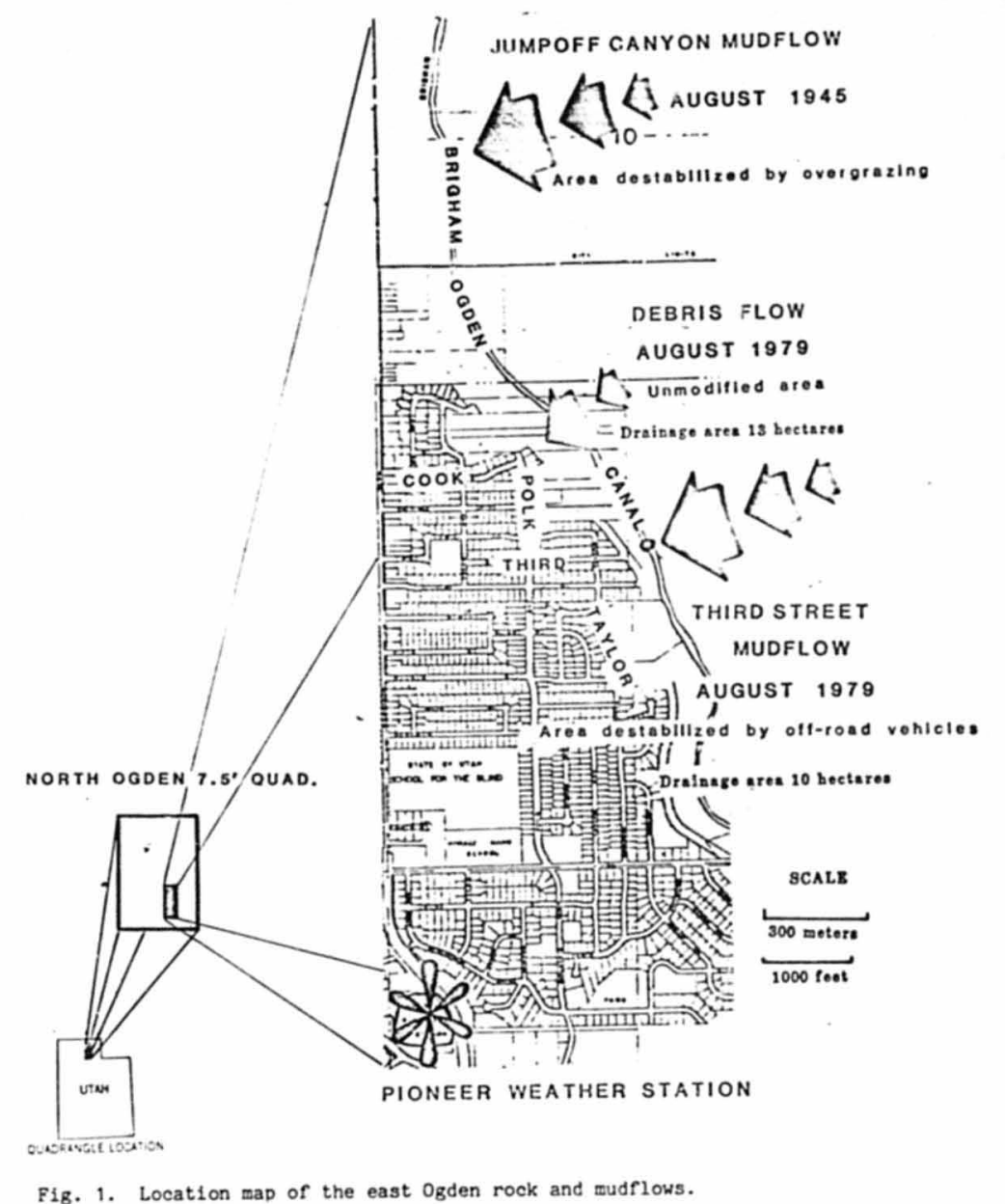

Many of the holses damaged by the flood were built on surfacts of terrsces and alluvial fans that are actively aggrading during heavy rains and are fed by west-facing catchment areas that capture the maximum amount of precipitation from eastward moving storms. Even without destabiiization of adfacent hilislopes by ORV's, the continuing processes of erosion and deposition were dramatically illustrated in the drainage just east of cook Street (Fig. 2). There boulders of Tintic Quartzite (Cambrian) and crystalline rock, as large as 1.5 meters in diameter, were deposited along braided distributary channels. Designers of the Brigham-Ogden Canal were aware of the hazard of high erosion rates, and as a result, the canal is covered where 1t intersects natural distributary channels. This precautionary measure prevented clogging of the canal at those points, including that just east of Cook Street.

The bedrock underlying the upper catchment areas is primarily Cambrian quartzite, limestone, and dolomite overlain by shallow solls that do not support a mature vegetative cover. The shallow soils, sparse vegetation, and steep slopes of the Wasatch Range front lead to high discharge after intense rains. The discharge from most storms is accommodated without major damage to cultural features. However, this matural system is precariously balanced, and any disturbance within 1 t tends to increase the posential for erosion and downslope damage to man-made structures.

\section{HISTORICAL PERSPECTIVE:}

Cloudburst floods along the Wasatch Range front are historically very common. Butler and Marsell report (Marse11, 1971) that 373 floods occurred 
during the 124-year span between 1845 and 1969. The geologic record suggests that there were debris flows in the past, but the frequency and intensity of floods have increased (Marsell, 1971). Whether increased flooding is related to overgrazing, logging, road bullding, and other factors that destroy the vegetative cover or to recent changes in climatic conditions is still unresolved.

A man-induced debris flow occurred in August 1945 when a rock and mudflow covered farmland at the mouth of Jumpoff Canyon, $1.5 \mathrm{~km}$ north of the August 1979 mudrlow (Fig. 3) (Robert Eldard, written comsun., Oct. 29, 1979, Ogden City Planning Combission). Overgrazing during the spring and summer months had denuded the hillsides and left the land extremely vulnerable to erosion. Under similar circumstances, the southern San Joaquin Valley of California was devastated by wind and subsequent rains in December 1977 (W11shire and others, in press). The loss of vegetative cover in both the Ogden and Bakersfield areas contributed to increased runoff sufficient to overload the dralnage systems. Records from the Pioneer Weather Station in Ogden indicate that 3.58 $\mathrm{cm}(1.4 \overline{\mathrm{C}}$ inches) of rain was sufficient to trigger the 1945 mudside.

\section{METHODS OF STUDY:}

Erosion of the ORV trails was examined by profiling methods described by wilshire and Nakata (1978). The profiles allow calculation of minimum total volumes of surficial material eroded from the ORV trails up to the time the seasurements were made. Soil samples were taken for bulk density measurements (Table 1). Mass losses by erosion of the ORV trails were then computed from voluse losses and bulk density values.

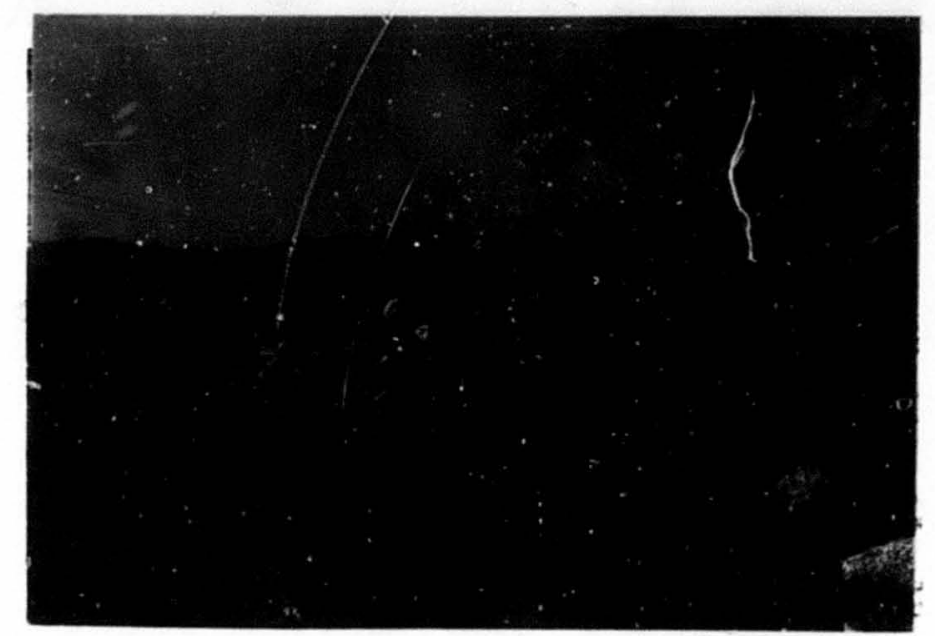

Fig. 2. Rocks as large as 1.5 meters in diameter were deposited on the covered segment of the canal east of cook Street. The upstream drainage system is unmodified by man. 


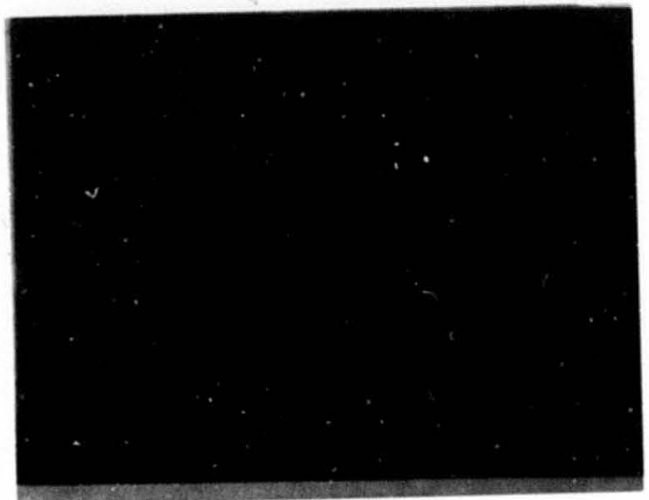

TABLE 1. BULK DENSITY OF SOIL SAMPLES LOCATION BULK DENSITY RANGE Above canal

RESULTS:

The major destabilized areas above the canal are hillclimbs that have been stripped of their vegetative and soll cover by ORV's and, as a result, have been altered both physically and chemically. Studies by Wilshire and Nakata (1976), Webb and others (1978), and Wilshire and others (1978a) have demonstrated that soil in denuded areas responds with a systematio increase in surface strength, bulk density, and diurnal temperature range, accompanied by a marked decrease in nutrients, infiltration, moisture, and organic material. All these factors combine to decrease productivity in the soil and inhibit. regrowth of vegetation. These denuded areas are then extremely susceptible to erosion (Fig. 4). In the study area, the material eroded from these gullies combined to form a debris flow sufficient to block flow in the Brigham-ogden Canal.

Erosion of ORV trails. To ensure that most of the volumetric loss from the ORV trails was the result of water erosion from the August storm and not pre-storm mechanical erosion by ORV's, calculations were biased to that end. Where applicable, transect-area calculations were made from the ORV trail surface and not from the original ground surface. In addition, deep gullies that appear on the 1975 aerial photograph supplied by the Ogden Planning Commission were not included in the calculations of mass loss. Living grasses still attached at their root tips in the bottom of many gullies provide

F1g. 3. A 1945 photograph shows overgrazed hillsides in Jumporf Canyon (A), and the debris flow after August 1945 rains (B). Photographs courtesy of the Ogden City Planning Commission. 
additional evidence that most of the gullies were the result of the August rainstorm. The length of the exposed roots indicates the amount of soil that had been eroded.

Profiles were made of two trails located above the canal to establish the order of magnitude of material eroded from the impaeted hillside (Fig. 5). A 330 -meter section of a trail located on an interfluve with a slope range of $10^{\circ}$ to $35^{\circ}$ was profiled to determine soil loss. The volume lost was $187 \mathrm{~m}^{3}$ with a mass 1035 of 325 or 359 metric tons, which corresponds to dry bulk densicy measurements of $1.74 \mathrm{~g} / \mathrm{cm}^{3}$ and $1.92 \mathrm{~g} / \mathrm{cm}^{3}$. A second trail 120 meters long with a slope range of $10^{\circ}$ to $23^{\circ}$ lost $72 \mathrm{~m}^{3}$ of soll yieldirg values of 125 or 138 metric tons depending on which bulk density measurement is used.

The total minimum loss from the tro trails is estimated as 450 metric tons of material. This figure does not apply to the entire destabilized area, nor does it account for natural erosion. Consequently, the volume loss reported represents only a partial estimate of the material eroded from the hills above the canal. However, the material displaced and channeled by ORV trails was sufficient to block the Brigham-0gden canal which measures only 2.8 $\mathrm{m}^{2}$ in cross-sectional area (Fig. 5).

Vegetative and soil factors. Vegetation cover and soil type gignificantly affect erosion potential. The importance of vegetation in retarding erosion on ORV sites is discussed by W11shire and others (1978b). In addition, recent studies by Wilshire and Nakata (unpub. data) have shown that sandy solls derived from crystalline rock are the most vulnerable to erosion.

Vegetation in the form of grasses, shrubs, and trees decreases erosion potential by: (1) forming a canopy to decrease rain impact, (2) adding humus to the soil to increase absorption, (3) decreasing the velocity of sheetwash,

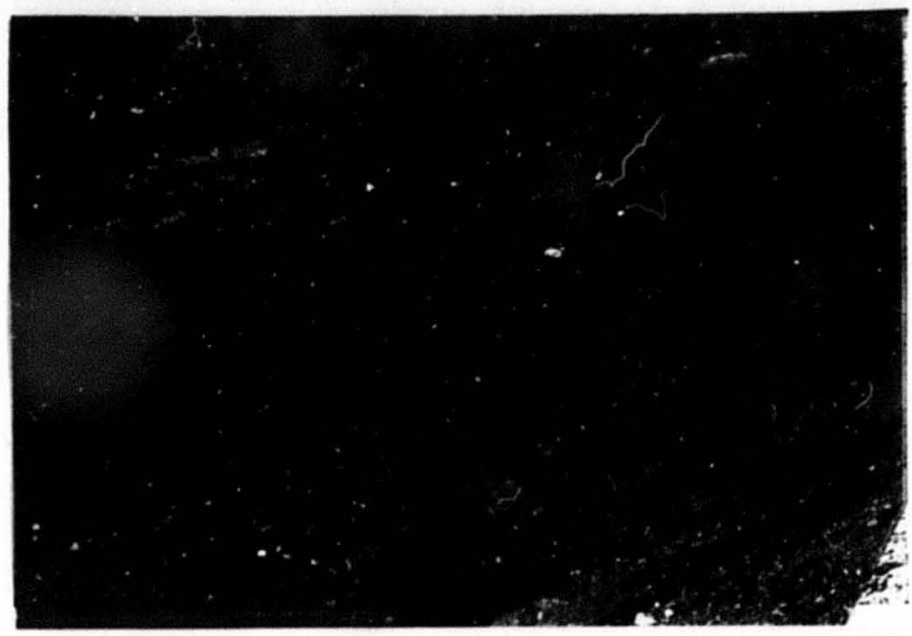

F1g. 4. Anastomosing gullies formed after August rains in all denuded areas. The string marks profile 7 (Fig. 5) along trail 1 and is approximately 11 meters long. 
and (4) binding soil particles together with root systens. However, road construction, overgrazing, logging, and ORY use that denude areas have the reverse effect.

The imsture soils underlying most of the ORV trails are derived from a medium- to coarse-grained gneissic quartz monzonite. This rock weathers into sand-size particles with little clay and combines with cobbles and boulders brought in by the distributary system and mass wasting to form a moderate to poorly sorted soll horizon of low erosional stability.

In the area above the canal (Fig. 5), two $75-\mathrm{m}^{2}$ plots, each with the same slope, slope aspect, and soil and both receiving excess runoff from denuded upslope terrin, were profiled to determine volume loss. The plot that was partially denuded by moderate ORV use lost $10 \mathrm{~m}^{3}$ of soil, whereas the adjacent area subjected to $11 \mathrm{ght}$ ORV use lost $4 \mathrm{~m}^{3}$. In areas not used by ORV's, the grass was matted by sheetflow, but the soil horizon was virtually intact.

Erosion below the canal. According to the Ogden Water Users Association, the Brigham-Ogden Canal was shut down on the morning of August 18 at $2: 45 \mathrm{a} . \mathrm{m}$. and was dry by 3:20 a.m. a running time of 35 minutes (Bill Burbidge and Ralph Bird, oral comrun., Sept. 24, 1979). They also reported a flow rate of 55-60 sec/ft, which translates to approximately 800,000 to 900,000 gallons of water diverted over the canal embankment. According to the August 18, 1979 issue of the Ogden Standard-Examiner, boulders were belng swept along Third Street just after 2:00 a.m.; therefore the canal may have topped before 2:00 a.m., and the running time may have been 80 minutes. If so, approximately 2 million gallons or water was diverted. Using the cross sectional area of the water in the canal $2.07 \mathrm{~m}^{2}\left(22.5 \mathrm{ft}^{2}\right)$ and the distance from the surge tank to Third street $2.56 \mathrm{~km}$ ( 1.6 miles), but not the flow rates, a value of approximately 1.4

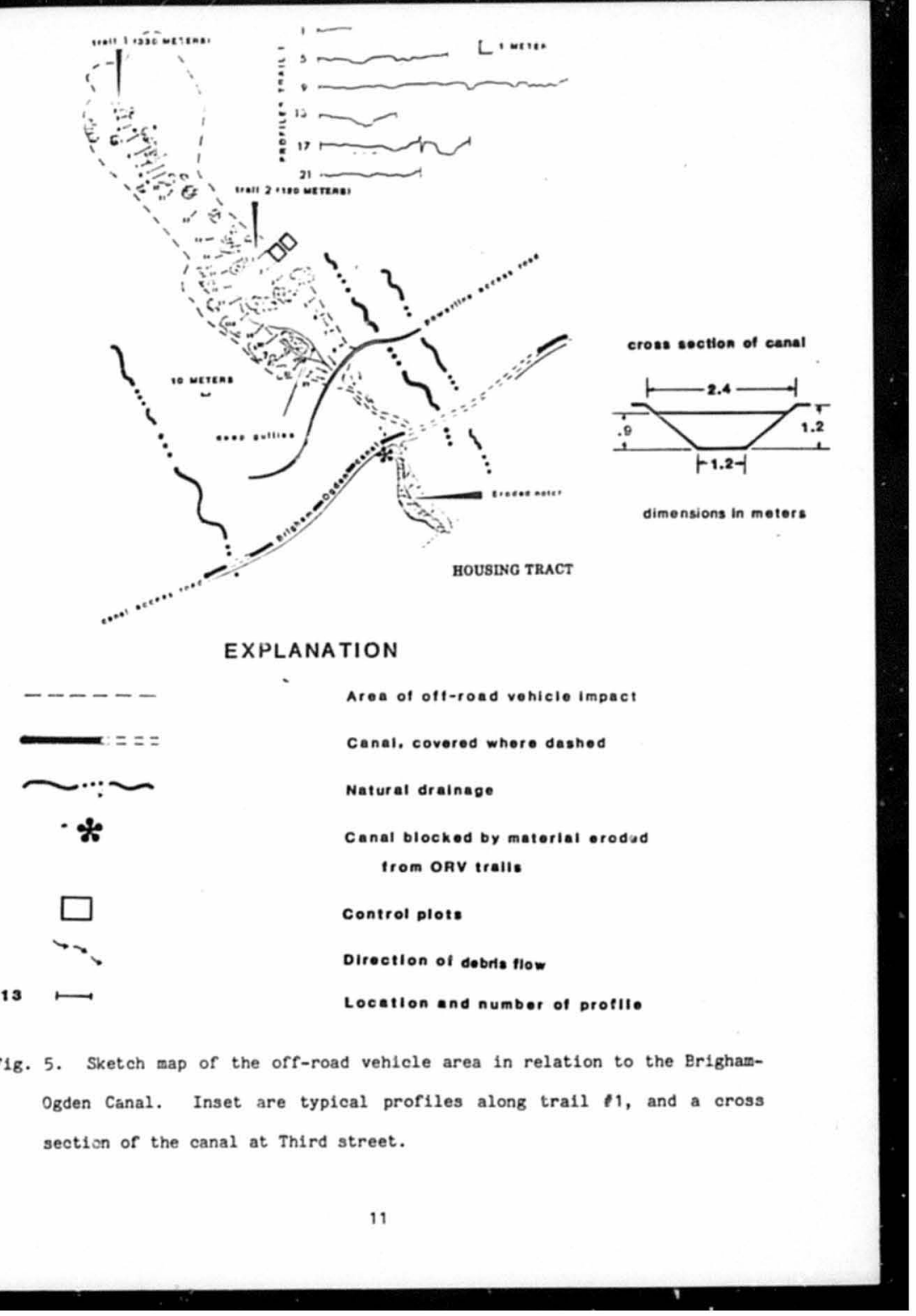


million gallons is computed. These values are approximate orders of magnitude of water diverted over the canal embankment.

Grading done after the mudflow to protect houses from subsequent rains changed the configuration of the notch below the canal. Consequentiy, only crude measurements were made on this notch. A conservative estimate of the volume displaced is $12,000 \mathrm{~m}^{3}$ or approximately 21,000 metric tons, on the basis of an average bulk density of $1.82 \mathrm{~g} / \mathrm{cm}^{3}$. The erosion that occurred below the canal is dramatically illustrated in Fig. 6, which shows the hillside before and after the debris flow.

SUMMARY:

Damage from the 1977 storm can be traced directly to several geologic processes which constitute hazards in the Ogden area. The steep slopes of the Wasatch Renge front are the result of Holocene faulting. Along the range front, mechanical weathering of the Tintic Quartzite cliffs by frost wedging forms unstable talus slopes. "Below these talus slopes, immature alluvial fans sti:1 grow after intense rains.

The historical record of debris flows along the Wasatch front, in particular' at Jumporf Canyon in 1945, constitutes evidence of land instability. The designers of the Brigham-Ogden Canal were awa'e of these constraints and took precautions to cover the canal at all active distributaries.

The areas upslope from Cook and 3rd streets (Fig. 1) have similar drainage sizes, slopes, slope aspects, rock types, and vegetative communities. The only significant difference is ORV modification to the 3 rd street area. Within this precariously balanced natural system, the added burden of material eroded from, and channeled by the ORV trails blocked the
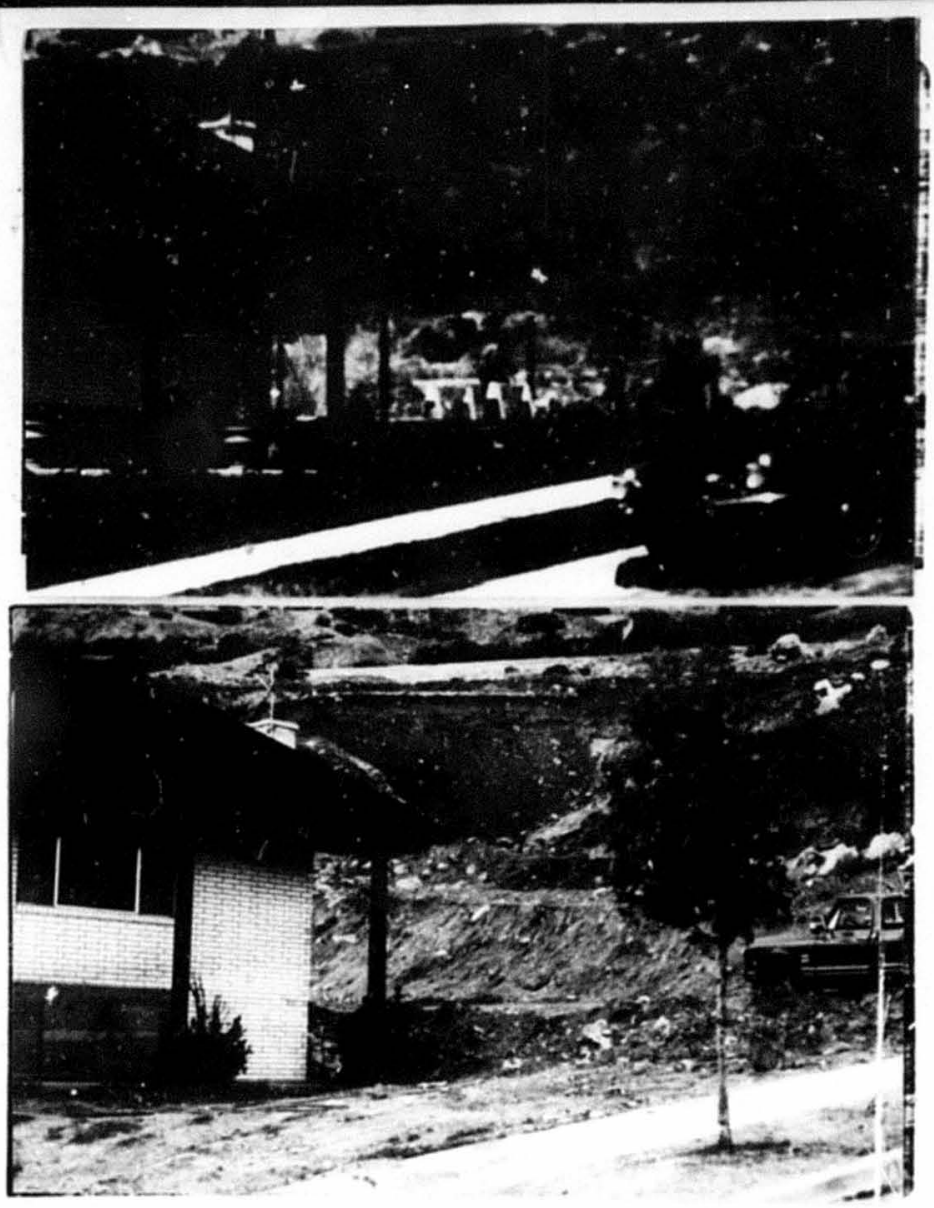

Fig. 6. Before and after photographs of the notch eraid by diverted cana: water at the end of Third Street. Photograph ( $h$ ) courtesy of Mr. and Mrs. L. Haun. 
canal and diverted canal water, contributing significantly to the damage of structures downslope. Kaliser (1979) also concluded that terrain modification by ORV' $s$ was the major contributing factor to the chain of events leading to flood damage.

\section{ACKNOWLEDGMENTS:}

I thank the Ogden City and Weber County Planning Commissions, particularly Mr. Robert Eldard for supplying photographs and data concerning the 1945 rock and mudflow in Jumpoff Canyon. I am grateful to Mr. Ralph Birc of the Ogden River Water Users Association, and Mr. and Mrs. L. Haun, flood victims, who contributed valuable information concerning the 1979 flood.
REFERENCES:

Kaliser, B, N., 1979, Off-road vehicle tracks trigger Ogden flood: Utah Geological and Mineral Survey, Survey Notes, v. 13, n. 4, p. 3.

Marsell, R. E., 1971, Cloudburst and snowmelt floods: in Environmental Geology of the Wasateh Front, 1971, Utah Geological Association Publication 1, p. N1-N18.

Sorensen, M. L., and Crittenden, M. D., Jr., 1972, Preliminary Geologic Map of Part of the Wasatch Range near North Ogd

Kebb, R. H., Ragland, H. C., Godwin, W. H., and Jenkins, D., 1978, ane: Environmental Management, v. 2, n. 3, p. 219-230.

Wilshire, H. G., Nakata, J. K., 1976, off-road vehicle eff-t ts on Calíornia's Mojave Desert: California Geology, v. 29, p. 123-132.

Wilshire, H. G., Nakata, J. K., 1978, Erosion off the road: Geotimes, v. 22, n. $7 / 8$.

Wilshire, н. G., Nakata, J. K., Shipley, S., and Prestegaard, K., 1978a, the San Francisco Impacts of vehicles on natural terrain at seven

W11shire, H. G., Shipley, S., and Nakata, J. K., 1978b, Impacts of off-road vehicles on vegetation: in Transactions of the 43rd North American Wild11fe and Natural Resources Conference, 1978.

Wilshire, H. G., Nakata, J. K., and Hallet, B., in press, Field observations of the December 1977 windstorm, San Joaquin Valley, California: in Pewe, Geological Society of America Memoir. 